\title{
PENERAPAN PEMILU BERINTEGRITAS DAN JAMINAN KESETARAAN HAK POLITIK DALAM PENDAFTARAN PEMILIH: STUDI KASUS PADA PILKADA SAMOSIR TAHUN 2015
}

\author{
Tota Pasaribu R $\mathbf{R}^{\mathbf{1}}$, Widya Setiabudi Sumadinata ${ }^{\mathbf{2}}$, dan Muradi $^{\mathbf{3}}$ \\ ${ }^{1}$ Komisi Pemilihan Umum Kabupaten Samosir, Provinsi Sumatera Utara \\ ${ }^{2}$ Departemen Hubungan Internasional, Fakultas Ilmu Sosila dan Ilmu Politik, Universitas Padjadjaran \\ ${ }^{3}$ Departemen Ilmu Pemerintahan, Fakultas Ilmu Sosila dan Ilmu Politik, Universitas Padjadjaran \\ E-mail: totapasaribu48@gmail.com s
}

\begin{abstract}
ABSTRAK.
Tahapan Pilkada Kabupaten Samosir tahun 2015 khususnya pada pendaftaran pemilih menuai berbagai kendala. Integritas dari Pemilu mengharuskan adanya jaminan kesetaraan hak-hak politik dan hak pilih universal pada setiap warga negara. BerdasarkanData Penduduk Potensial Pemilih Pemilihan (DP4) yang disediakan oleh Kementerian Dalam Negeri, sebagai sumber awal pendataan yang kemudian dimutakhirkan dengan data di lapangan, ditemukan sejumlah calon pemilih yang sudah berhak memilih namun tidak terdaftar dalam DP4 karena ketiadaan dokumen kependudukan sehingga secara administrasi mereka tidak berhak untuk didaftarkan. Komisi Pemilihan Umum Kabupaten Samosir sebagai penyelenggara Pemilu berusaha melindungi hak konstitusi setiap warga negara tanpa terkecuali dengan mengakomodir mereka melalui penggunaan Surat Keterangan Domisili (SKD) yang hanya dikeluarkan oleh Kepala Desa/Lurah.Namun sesuai Undang-undang Adminitrasi Kependudukan hal ini bukan bagian dari dokumen kependudukan.Permasalahan yang muncul adalah bagaimana efektivitas kehadiran SKD dalam melindungi hak pilih warga.Adapun penelitian ini menggunakan metode kualitatif deskriptif dengan menggunakan konsep Pemiluberintegritas dan kesetaraan hak politik sebagai pisau analisis. Hasil analisis menunjukan bahwa akomodir penggunaan SKD tersebut dinilai efektif melindungi hak pilih warga yang sebelumnya terancam hilang yaitu mereka dari kalangan pemilih pemula, pemilih apatis terhadap dokumen kependudukan dan pemilih dari penganut aliran kepecayaanParmalim. Pada akhir tulisan ini, penulis menyarankan dalam rangka pemberian jaminan hak pilih melalui akurasi data Pemilu, diperlukan adanya penyesuaian regulasi antara teknis pendataan pemilih dengan kependudukan, memelihara data base pemilih secara berkelanjutan dan integrasi data base pemilih dengan data administrasi kependudukan.
\end{abstract}

Kata Kunci: Pemilu; hak politik; pendaftaran pemilih; Surat Keterangan Domisili (SKD)

\section{THE IMPLEMENTATION OF INTEGRATED GENERAL ELECTION AND GUARANTEED EQUALITY OF POLITICAL RIGHTS IN VOTERS REGISTRATION: CASE STUDY OF THE 2015 REGIONAL ELECTIONS IN SAMOSIR}

\begin{abstract}
.
The 2015 Samosir District Election reap various obstacles especially in the voter registration stage. The integrity of elections requires guarantees of political rights equality and universal suffrage for every citizen. Based on the Electoral Potential Population Data (DP4) that provided by the Ministry of Home Affairs, which was enlivened with a fieldwork data, it was found that some prospective voters were not registered in DP4 because their name was not listed in the population documents. The General Election Commission (KPU) of Samosir Regency had tried to protect the constitutional rights of every voter without exception by accommodating them through the use of a Domicile Certificate (SKD) data which was only issued by the Village Head or Lurah. However, according to the Population Administration Law, the SKD was not part of the population document. The problem that arises was how effective the presence of SKD in protecting the voter's rights. The study uses a descriptiveanalytical method that using the concept of elections integrity and equality of political rights. The results of this study show that accommodating the SKD is considered to be useful in protecting the voting rights of the voters who were previously unable to vote, mainly from the beginner voters, apathetic voters, and adherents of the Parmalim sect. At the end of this paper, the authors suggest that in order to ensure the voting rights of all voters through the accuracy of election data, the regulatory adjustments should be made both in the unique voter data collection and population. It is also important to maintain a voter database continually and integrate the voter database with population administration data.
\end{abstract}

Key words: election; political rights; voters' registration; domicile certificate 


\section{PENDAHULUAN}

Hak pilih merupakan hak yang sangat mendasar bagi seluruh warga negara tanpa terkecuali. Negara memberikan jaminan perlindungan akan hak warganya yang memenuhi syarat untuk didaftar sebagai pemilih melalui aturan hukum berupa jaminan hak pilih (Santoso, 2006).

Dalam Konvenan Internasional Sipil dan Politik, ICCPR (International Convenan on Civil and Political Rights) disebutkan bahwa keberadaan hak-hak dan kebebasan dasar manusia yang bersifat absolut tidak boleh dikurangi walaupun dalam keadaan darurat. Hak bebas dari pemidanaan yang bersifat surut, hak sebagai subjek hukum, kebebasan berpikir, berkeyakinan atau agama. Begitu juga hak dalam memilih dan dipilih dalam suatu pemilihan yang diselenggarakan secara periodik yang bersifat universal. Hal ini mengindikasikan dimana hak politik baik memilih maupun dipilih adalah sebuah hak yang paling asasi. Indonesia merupakan negara yang penduduknya menganut berbagai agama termasuk aliran kepercayaan. Hampir di seluruh wilayah Indonesia telah ada agama atau aliran kepercayaan asli seperti Sunda Wiwitan yang dipeluk oleh masyarakat Sunda dan di Kanekes Kabupaten Lebak Banten, Sunda Wiwitan aliran madrais penamaan lain di Cigugur, Kejawen di Jawa Tengah dan Jawa Timur, Parmalim di Sumut, Kaharingan di Kalimantan, dan lain-lain. Penganut aliran kepercayaan ini sedikti terkendala dalam pengurusan KTP sebagai bagian dari dokumen adminstrasi kependudukan. Undang-undang mensyaratkan jika dokumen kependudukan merupakan bagian dari syarat administrasi dalam pendaftaran pemilih.

Menurut Ramlan Surbakti, integritas dari sebuah Pemilu adalah jika pelaksanaannya berdasarkan kepastian hukum yang dirumuskan sesuai asas Pemilu demokratis. Pemilu Berintegritas adalah Pemilu yang jauh dari praktik manipulasi Pemilu (electoral fraud), seperti penyimpangan lain termasuk manipulasi perhitungan suara, pendaftaran pemilih secara ilegal, intimidasi terhadap pemilih yang bertentangan dengan semangat undang-undang Pemilu atau merupakan pelecehan terhadap prinsipprinsip demokrasi. Manipulasi pemilihan seperti mencegah warga yang berhak memilih untuk memberikan suara secara bebas bahkan ada kalanya mencegah warga untuk memilih (Ramlan Surbakti D. S., 2011).
Integritas Pemilu terlihat jika Pemilu dapat terlaksana berdasarkan atas prinsip Pemilu demokratis dan pemenuhan hak pilih universal dan kesetaraan politik seperti yang tercermin pada standar Pemilu internasional dengan penyelenggaranya yang profesional, tidak memihak dan senantiasa transparan yang dilaksanakan melalui suatu siklus Pemilu. Demikian juga seharusnya jika ingin mewujudkan integritas Pemilu, maka dalam hal jaminan hak untuk memilih dan dipilih, dibutuhkan adanya kerangka hukum yang mengakomodir semua warga negara yang memenuhi syarat dijamin bisa ikut dalam pemilihan tanpa diskriminasi.

Adapun yang menjadi salah satu parameter yang terdapat dalam standar Pemilu demokratis menurut Robert A. Dahl adalah inclusiveness, artinya setiap orang yang sudah dewasa harus diikutkan dalam Pemilu karena mempunyai kesempatan yang sama. Sedangkan equal vote, artinya setiap suara mempunyai hak dan nilai yang sama tanpa adanya suatu diskriminasi (Supriyanto, 2007). Keberadaan suatu formulasi yang mewajibkan pemutakhiran daftar pemilih secara transparan dan akurat, dengan jaminan perlindungan akan hak warga negara yang memenuhi syarat untuk didaftar dan mencegah pendaftaran orang secara tidak sah atau ilegal. Suatu kerangka hukum harus memastikan semua warga negara yang telah memenuhi syarat dijamin bisa ikut dalam pemilihan tanpa adanya diskriminasi (DKPP, 2015).

Permasalahan akan ketidakakuratan Daftar Pemilih Tetap (DPT) menjadi permasalahan krusial yang senantiasa muncul pada saat penyelenggaraan Pemilu/Pemilihan Kepala Daerah (Pilkada). Berbagai protes ditujukan ke KPU, karena sejumlah calon pemilih tidak terdaftar dalam DPT sehingga tidak bisa memberikan suaranya dalam Pemilu. Kementerian Dalam Negeri (Kemendagri) sebagai sumber data pemilih, menyiapkan data mentah berupa Daftar Penduduk Potensial Pemilih Pemilihan (DP4) berdasarkan data administrasi kependudukan dan catatan sipil untuk disinkronisasi oleh KPU. Sebuah permasalahan yang terjadi dalam perwujudan Pemilu berintegritas dalam pemberian jaminan perlindungan hak pilih warga khsusnya pada tahapan pendaftaran Pemilih dalam Pilkada Kabupaten Samosir, Provinsi Sumatera Utara tahun 2015. Kendati pada akhirnya Pilkada Samosir telah menghasilkan pemimpin dengan terpilihnya pasangan Bupati dan Wakil Bupati Samosir periode 2016-2021. 
Salah satu kendala dan keunikan pada tahapan Pilkada Kabupaten Samosir tahun 2015 yaitu pada pendaftaran penduduk yang memenuhi syarat untuk didaftarkan sebagai pemilih, namun tidakmemiliki identitaskependudukan, melainkan hanya Surat Keterangan Domisili (SKD) yang dikeluarkan oleh Kepala Desa/Lurah sebagai instansi yang berwenang. Menurut beberapa pihak dalam Pilkada Samosir tahun 2015, kehadiran dan akomodir terhadap pengguna SKD tersebut, dinilai bertentangan dengan Undangundang Administrasi Kependudukan. Keadaan ini, sepatutnya diduga telah terjadi pelanggaran kode etik oleh penyelenggara Pemilu tersebut.

Pihak KPU Samosir berprinsip bahwa SKD tersebut adalah sebagai jalan satu-satunya dalam melindungi hak pilih warga. Dengan mengartikan jika SKD masuk dalam kategori sebagai identitas lainnya yang digunakan dalam adminstrasi pendaftaran pemilih. Hal ini adalah sebagai inisiasi dalam pelaksanaan demokrasi yang semakin kompleks, dimana pemenuhan hak politik masyarakat adalah merupakan suatu tujuan utama (Budiman, 2015).

Beberapa penelitian kualitatif sebelumnya berkaitan dengan penelitian ini adalah penelitian yang dilakukan oleh Rahmathulloh (2016), terkait tahapan penyusunan data pemilih Pilkada Daerah Khusus Ibukota (DKI) Jakarta tahun 2017, dalam temuannya disimpulkan ter-kait keabsahan daftar penduduk berbasis data base kependudukan dari pemerintah melalui Dinas Kependudukan dan Pencatatan Sipil Provinsi DKI Jakarta dan implikasinya dengan sejumlah pemilih yang belum memiliki identitas kependudukan elektronik. Mengandalkan Suket dari Disdukcapil semata tanpa keterangan RT/ RW, sangat riskan adanya penyelewengan atau penyalahgunaan identitas sehingga, tidak mengantisipasi adanya kecurigaan pengerahan masa pemilih dari luar daerah yang disinyalir dilakukan pasangan tertentu untuk datang di TPS saat pemungutan suara. Untuk itu sangat diperlukan adanya pemutakhiran melalui pencocokan dan penelitian (coklit) data ke lapangan melalui PPS dan PPDP secara face to face, untuk menghasilkan data pemilih berkualitas sebagaimana data kependudukan yang semestinya dan validitasnya memberi kepastian bahwa setiap penduduk DKI Jakarta adalah warga pemilih yang sesungguhnya.

Penelitian yang dilakukan oleh Asy'ari (2012), terkait arah sistem pendaftaran pemilih
Indonesia. Dalam temuannya menjelaskan bahwa pemilih masuk dalam tiga kategori yaitu, pemilih terdaftar yang berhak, pemilih terdaftar tidak berhak dan pemilih yang berhak namun potensial tidak terdaftar, dengan berbagai kategori. Kemudian penelitian yang dilakukan oleh Sri Nuryanti (2017), terkait hilangnya suara warga negara, jebakan formalisme dan perumitan dalam regime elektoral. Rigidnya Undangundang Administrasi Kependudukan yang hanya bepedoman pada persoalan administrasi semata tanpa mementingkan data kependudukan yang valid dan komprehensif sesuai fakta di lapangan pada Pemilu 2009 berakibat hilangnya hak pilih warga negara yang tidak dapat menggunakan hak pilihnya karena namanya tidak terdaftar dalam DPT pada Pileg dan Pemilihan Presiden (Pilpres) 2009.

Sedangkan penelitian ini sendiri menganalisis Pemilu berintegritas dari sisi akomodir berupa pendataan pemilih terhadap pemilih yang tidak memiliki dokumen kependudukan dengan menjadikan SKD sebagai dokumen administrasi dalam pendatan pemilih dengan efektivitasnya dalam melindungi hak pilih setiap warga negara secara universal.

\section{METODE}

Penelitian ini menggunakan pendekatan kualitatif deskriptif berupa studi kasus dengan membangunpernyataan pengetahuanyang dieksplorasi dalam penelitian, partisipan penelitian dan lokasi penelitian (Creswell, 2016), dan pada akhirnya tidak akan menghasilkan data statistik. Hal ini menuntut peneliti untuk menganalisa proses akomodir tesebut dan efektivitasnya dalam melindungi hak pilih warga yaitu mereka yang sangat rentan akan kehilangan hak pilih dengan menitikberatkan pada proses wawancara mendalam terhadap informan yang ditentukan secara purpossive sampling. Demi akurasi data dan informasinya, dalam hal ini peneliti melakukan validitas data melalui trianggulasi yaitu teknik pemeriksaan keabsahan data dari sumber atau informan yang lainnya guna mendapatkan data pembanding yang didesain melalui studi kasus pada rangkaian waktu tertentu, dan melalui pengumpulan data secara mendalam yang melibatkan banyak informasi yang sesuai dan kaya akan konteks (Creswell, 1998). Adapun tujuannya adalah untuk membedah secara mendalam serta mengenal masalah- 
masalah serta mencari kebenarannya yang bekerja dengan suatu fase spesifik atau khas dari keseluruhan personalitas. Data dikumpulkan untuk dianalisis dengan beberapa tahapan seperti wawancara mendalam terhadap informan dan dokumentasi.

Proses wawancara dilakukan terhadap informan yaitu pihak-pihak yang terlibat pada proses pelaksanaan pendataan pemilih terhadap pengguna SKD pada Pilkada Samosir Tahun 2015 yaitu Ketua Komisi Pemilihan Umum Kabupaten Samosir, Panitia Pengawas Pemilihan Kabupaten Samosir. Selain itu juga dikumpulkan pendapat atau tanggapan serta masukan dari LSM di bidang Politik dan Pemilu, Akademisi di bidang kepemiluan, tokoh/ penganut aliran kepercayaan, perwakilan pemilih pengguna SKD dengan kategori 5 (lima) segmen pemilih strategis yang ditetapkan oleh KPU yaitu pemilih pemula, perempuan, basis agama, penyandang disabilitas dan segmen pemilih kaum marginal dan pihak lainnya yang dianggap relevan memberikan informasi.Tahapan pengumpulan data juga dilakukan dengan mengkaji dan menganalisis informasi dari sumber lainnya yaitu buku dan arsip pelaksanaan pemutakhiran data pemilih pada Pilkada Samosir tahun 2015 untuk selanjutnya dituangkan sebagai hasil penelitian ini.

\section{HASIL DAN PEMBAHASAN}

\section{Dinamika dan MobilitaspendudukKabupaten Samosir}

Terkait mobilitas penduduk Kabupaten Samosir sebagai suatu bentuk movement penduduk dari dan ke Kabupaten Samosir yang berpengaruh dalam proses pendataan pemilih dengan waktu pengukuran minimum enam bulan. Sedangkan yang dikatakan dengan migrasi oleh BPS adalah perpindahan penduduk dari suatu tempat ke tempat lainnya dengan maksud untuk menetap di daerah tujuan sekitar tahun 2015 (BPS Sumut, 2016).

Demikian halnya yang terjadi di Kabupaten Samosir, penduduk yang mempunyai mobilitasi (migrasi) karena alasan pindah didominasi oleh alasan ikut suami/istri/orang tua/anak. Pada Kategori karena pekerjaan dan pendidikan, banyak para penduduk tersebut, ketika masuk atupun keluar dari dan ke Kabupaten Samosir, tidak melengkapi dokumen administrasi kependudukan (BPS Sumut, 2016).
Tabel 1. \% Mobilitas penduduk Kabupaten Samosir dan Provinsi Sumatera Utara Tahun 2015

\begin{tabular}{lcc}
\hline \multirow{2}{*}{ Kategori (\%) } & \multicolumn{2}{c}{ Wilayah } \\
\cline { 2 - 3 } & Samosir & Sumut \\
\hline Pekerjaan & 16,29 & 23,97 \\
Pendidikan & 14,39 & 10,94 \\
Perkawinan & 7,11 & 4,57 \\
Ikut keluarga & 40,96 & 49,09 \\
Perumahan & 0,00 & 7,54 \\
Keamanan/ Relokasi & 0,00 & 0,36 \\
Bencana/Kerusakan & 0,00 & 0,26 \\
Lingkungan & & \\
Lainnya & 21,26 & 3,27 \\
\hline
\end{tabular}

Sumber: Diolah dari Badan Pusat Staistik Kabupaten Samosir

Pendataan Pemilih Terhadap Pengguna Surat Keterangan Domisili (SKD)

Berbagai hal yang menjadi temuan di lapangan dan sesuai hasil wawancara peneliti dengan beberapa informan dalam hal ini Ketua KPU Kabupaten Samosir (Suhadi S. Situmorang), mantan Kadis Kependudukan dan Catatan Sipil Kabupaten Samosir (Melani Butarbutar), dan perwakilan segmen pemilih serta seorang Tokoh Penganut aliran Kepercayaan Parmalim di Kabupaten Samosir.

Selama proses pemutakhiran data pemilih dengan berdasarkan pada Data Penduduk Potensial Pemilih Pemilihan(DP4) yang disediakan oleh Kemendagri, sebagai sumber awal pendataan yangkemudian dimutakhirkan dengan data di lapangan, ditemukan sejumlah calon pemilih yang sudah berhak memilih namun tidak terdaftar dalam DP4 karena ketiadaan dokumen kependudukan sehingga secara administrasi mereka tidak berhak untuk didaftarkan sebagai pemilih. Kondisi lainnya adalah adanya penganut aliran kepercayaan masyarakat batak toba yaitu aliran kepercayaan Parmalim yang sampai saat ini masih mengalami kendala dalam pengurusan dokumen kependudukan (KTP/ KK/ Akta Nikah dan dokumen lainnya). Selain itu ada warga yang disinyalir terindikasi memiliki KTP ganda dan terdeteksi di aplikasi SIDALIH, baik ganda antar TPS, Desa/Kelurahan, Kecamatan, Kabupaten bahkan Provinsi, NIK invalid dan NIK yang tidak sinkron dengan nama dan jenis kelamin.

Hal-hal tersebut, seperti diterangkan di atas, menjadi sangat rentan untuk tidak terdaftar 
dalam daftar pemilih. Sedangkan penyelenggara Pemilu berdalih jika SKD yang dikeluarkan oleh Kepala Desa/Lurah menjadi alternatif terakhir sebagai dokumen administrasi dalam pendataan pemilih. Apa yang dilakukan oleh KPU Kabupaten Samosir, patut diapresiasi sebagai upaya dalam manjamin dan melindungi hak pilih setiap warga negara. Kendati salah penyebabnya adalah terkait ketiadaan dokumen kependudukan dari calon pemilih itu sendiri. Adanya warga yang sudah memenuhi syarat untuk memilih, namun potensial untuk tidak memilih atau dalam kasus pilkada samosir tahun 2015 dimasukkan dalam pemilih pengguna SKD adalah mereka yang dikategorikan sebagai pemilih tanpa identitas kependudukan apapun (penduduk rentan administrasi kependudukan). Pemberlakuan penggunaan SKD sebagaimana diuraikan di atas adalah bagian dari identitas warga yang di dalamnya memuat terhitung mulai waktu tinggalnya (TMT) atau domisili tempat tinggalnya seseorang.

\section{Efektivitas Penggunaan Surat Keterangan Domisili dalam Melindungi Hak Pilih Warga}

Betapa pentingnya prinsip persamaan suara dalam setiap kontestasi politik, yaitu semua suara dihitung sama. Melalui penakaran nilai suara yang sama pada setiap pemilih, hal yang juga harus dituntut adalah integritas penyelenggara Pemilu dengan dasar profesionalisme dalam proses pendaftaran dan identifikasi pemilih. Dengan atas nama kedaulatan rakyat, maka Pemilu diwajibkan harus efektif, memberikan kedudukan yang sama kepada semua pihak, baik itu pemilihnya maupun pesertanya, sebagai upaya perlindungan dan jaminan hak pilih setiap warga negara, maka hal ini harus dimulai dari proses pendataan pemilih. Jika melihat pada keberadaan penggunaan SKD merupakan solusi terakhir untuk mengakomodir dan melindungi hak pilih warga yang sudah berhak didaftar sebagai pemilih. Namun pada sisi yang lain, mereka tidak memiliki dokumen kependudukan sebagai mana diamanatkan oleh Undang-undang Administrasi Kependudukan.

SKD merupakan suatu identitas warga yang isinya menerangkan keberadaan seseorang telah berdomisili di wilayah tersebut. Jika pendataan pemilih dilakukan dengan hanya berpedoman pada Undang-undang Administrasi Kependudukan tersebut, maka dalam hal ini telah terjadi sikap diskriminatif oleh penyelenggara dan sudah mengenyampingkan substansi dari Pemilu demokrais sebagai indikator untuk berintegritasnya sebuah Pemilu. Dalam hal ini, undang-undang tersebut lebih melihat kepada syarat administrasi semata, tanpa memperhatikan kondisi secara real di lapangan. Apabila Pemilu tidak dilaksanakan dengan basis integritas, maka akan berimplikasi pada minimnya partisipasi politik dan hilangnya kepercayaan publik pada proses demokrasi (Nasef, 2014)

Demi menjamin persamaan dan keadilan warga negara sebagai bagian dari prinsip demokrasi konstitusional, maka hak pilih warga negara dalam proses penetapan pemilih dapat dipastikan bagi setiap warga negara telah terakomodir secara utuh tanpa terkecuali, dengan tidak ada diskriminasi baik dari aspek SARA (Suku, Agama, Ras dan Antar golongan). Kepastian ini menjadi penting, mengingat penetapan pemilih merupakan suatu parameter tingkatan derajat demokrasi pada negara yang menganut paham pemerintahan rakyat. Semakin sedikit pemilih yang tidak terdaftar dalam data pemilih, maka semakin tinggi nilai demokrasinya, dan sebaliknya semakin besar pemilih yang tidak terdaftar dalam data pemilih, maka nilai demokrasinya rendah.

Munculnya 1.285 pemilih pengguna SKD dari total 94.454 pemilih yang terdaftar, adalah merupakan bentuk perlindungan terhadap hak politik warga. Hal ini sebagai perwujudan Pemilu berintegritas (electoral integrity) yang didasarkan pada pandangan bahwa Pemilu diselenggarakan untuk menjunjung tinggi sekaligus menegakkan hak asasi manusia dan prinsip demokrasi yakni bebas dan adil atau free and fair election. Adanya prinsip demokrasi dengan hak pilih yang berlaku secara universal dan adanya kesetaraan politik.

\section{Akomodir Penggunaan SKD bagi Penganut aliran kepercayaan Parmalim}

Adanya jaminan akan hak politik warga negara, termasuk keberadaan komunitas penganut aliran kepercayaan Parmalim di Kabupaten Samosir adalah sebuah realita sehingga hak-hak politik mereka senantiasa harus terjamin tanpa ada suatu golongan tertentu yang terdiskriminasi atau luput dari pendataan pemilih. Parmalim atau ugamo malim merupakan nama sebuah kepercayaan atau agama asli suku Batak. Kepercayaan Parmalim di tanah Batak sudah ada sejak jaman perjuangan Pahlawan Nasional Raja Sisingamangaraja XII. 
Sebaran Parmalim, saat ini di Kabupaten Samosir terkonsentrasi pada 5 Kecamatan, yang meliputi Desa Tomok dan Parmonangan di Kecamatan Simanindo, Desa Saor Nauli Hatoguan di Kecamatan Palipi, Desa Toguan Galung di Kecamatan Nainggolan, Desa Huta Hotang dan Sitamiang di Kecamatan Onan Runggu serta Desa Huta Ginjang di Kecamatan Sianjur Mula-mula dan sebagian kecil lainnya di beberapa Kecamatan di luar kelima Kecamatan tersebut. Untuk Kabupaten Samosir ada empat rumah ibadah bagi penganut Parmalim, masing di Kecamatan Onan Runggu (2), di Kecamatan (1) Palipi dan Tomok Kecamatan Simanindo (1), dimana haris sabtu adalah jadwal (Asnawati, 2013).

Proses akomodir penggunaan SKD terhadap komunitas penganut kepercayaan Parmalim oleh KPU Kabupaten Samosir adalah sebagai akibat terkendalanya pemenuhan dokumen administrasi kependudukan mereka. Penganut kepercayaan Parmalim mengalami berbagai permasalahan dari aspek pemenuhan hak-hak dasar dan kebijakan publik. Banyak ketidakcocokan antara identitas agama yang dituliskan di Kartu Keluarga dan KTP elektronik. Selain itu, pihak kepala lingkungan yang bertugas mengurus KK dan KTP elektronik sering memaksa kelompok Parmalim untuk memilih agama yang diakui agar proses pembuatan KTP elektronik dikatakan lebih mudah.

Tabel 2. Data Pemilih penganut kepercayaan Parmalim pada Pilkada Samosir Tahun 2015

\begin{tabular}{|c|c|c|c|}
\hline \multirow{2}{*}{ No } & \multirow{2}{*}{ Kecamatan } & \multicolumn{2}{|c|}{ Jumlah } \\
\hline & & Non SKD & SKD \\
\hline 1 & Pangururan & 0 & 0 \\
\hline 2 & Simanindo & 16 & 9 \\
\hline 3 & Ronggur Nihuta & 0 & 0 \\
\hline 4 & Palipi & 16 & 7 \\
\hline 5 & Nainggolan & 29 & 12 \\
\hline 6 & Onan Runggu & 14 & 15 \\
\hline 7 & Sianjur Mula-mula & 8 & 0 \\
\hline 8 & Harian & 2 & 0 \\
\hline 9 & Sitio-tio & 0 & 0 \\
\hline & Jumlah & 85 & 43 \\
\hline & Total & \multicolumn{2}{|c|}{128} \\
\hline
\end{tabular}

Sumber: Diolah dari beberapa sumber yaitu Badan Pusat Statistik Republik Indonesia, Subbag Program dan Data KPU Kabupaten Samosir dan Dinas Kependudukan dan Catatan Sipil Kabupaten Samosir
Aturan perundang-undangan mewajibkan para penghayat kepercayaan atau penduduk yang agamanya belum diakui diharuskan untuk tidak mengisi kolom agama dalam KTP, tetapi tetap dilayani dan dicatat dalam database kependudukan. Namun pada kenyataan di lapangan, parapenghayatkepercayaanyangmengosongkan kolom agama di KTP tidak mendapatkaan pelayanan yang setara sebagaimana warga negara pada umumnya, bahkan mengalami diskriminasi. Padahal memiliki identitas yang lengkap dan diakui merupakan keinginan dan kewajiban bagi setiap warga negara Indonesia. Hal inilah yang menjadi keinginan sekaligus permasalahan yang dihadapi umat Parmalim. Mereka berkeinginan mempunyai identitas yang diakui sebagai warga negara Indonesia. Penganut aliran kepercayaan Parmalim banyak yang memilih dan rela untuk tidak memiliki dokumen kependudukan KTP daripada harus dipaksa memilih salah satu dari 6 (enam) agama yang diakui di Indonesia, walapun tidak tertutup kemungkinan jika sewaktu-waktu mereka harus tunduk kepada syarat dan kenyataan tersebut. (Sitohang, 2016).

Tahapan pendaftaran pemilih dengan ditemukan calon pemilih yang tidak memiliki identitas kependudukan termasuk penganut Parmalim yang hanya memiliki SKD yang tidak dikenal dalam Undang-udang kependudukan, padahal jaminan akan hak pilih dari setiap warga negara yang sudah berhak menggunakan hak pilih merupakan hal yang mutlak dilakukan. KPU Kabupaten Samosir melakukan akomodir terhadap pengguna SKD untuk didaftarkan sebagai pemilih. Hal ini dilakukan bukan tidak beralasan. Selain pada Pilkada 2015, dalam beberapa Pemilu sebelumnya seperti pada Pileg 2014, kehadiran SKD bagi penganut Parmalim seolah sudah menjadi ciri khas dari Kabupaten Samosir. Secara de facto ditemukan calon pemilih penganut Parmalim yang tidak memiliki KTP namun berdomisili di Kabupaten Samosir dan sudah memenuhi ketentuan formulasi untuk didaftarkan sebagai pemilih.

Kehadiran dan akomodir penggunaan SKD merupakan langkah alternatif sebagai upaya dari Komisi Pemilihan Umum yang wajib melindungi hak pilih warga tanpa terkecuali terkhusus bagi mereka yang tidak memiliki KTP atau indentitas kependudukan. Para penganut Parmalim di Kabupaten Samosir sudah sejak lahir menjadi penduduk Kabupaten Samoir 
bahkan jauh melebihi jangka waktu minimal 6 bulan sebelum Daftar Pemilih Sementara (DPS) ditetapkan. Namum ketiadaan dokumen kependudukan seperti KTP dan Kartu Keluarga bukanlah menjadi alasan untuk menghilangkan hak pilih mereka.

Tabel 3. Perbandingan Data Pemilih Pengguna SKD pada Pemilihan Legislatif (Pileg) Tahun 2014 \& Pilkada Tahun 2015 di Kabupaten Samosir

\begin{tabular}{|c|c|c|c|}
\hline \multirow[b]{2}{*}{ No } & \multirow[b]{2}{*}{ Kecamatan } & \multicolumn{2}{|c|}{ Jumlah } \\
\hline & & $\begin{array}{l}\text { Pileg } \\
2014\end{array}$ & $\begin{array}{c}\text { Pilkada } \\
2015\end{array}$ \\
\hline 1 & Pangururan & 1.251 & 144 \\
\hline 2 & Simanindo & 1.095 & 436 \\
\hline 3 & Ronggur Nihuta & 323 & 103 \\
\hline 4 & Palipi & 332 & 113 \\
\hline 5 & Nainggolan & 489 & 77 \\
\hline 6 & Onan Runggu & 410 & 153 \\
\hline 7 & Sianjur Mula-mula & 418 & 44 \\
\hline 8 & Harian & 384 & 88 \\
\hline 9 & Sitio-tio & 313 & 127 \\
\hline & Total DPT & 90.733 & 94.454 \\
\hline & $\begin{array}{l}\text { lah pengguna SKD } \\
\text { dari total pemilih) }\end{array}$ & $\begin{array}{l}5.015 \\
(5,52)\end{array}$ & $\begin{array}{l}1.285 \\
(1,36)\end{array}$ \\
\hline
\end{tabular}

Sumber: Diolah dari Komisi Pemilihan Umum Kabupaten Samosir

Walaupum keberadaan SKD tidak secara eksplisit disebutkan dalam Undang-undang Nomor 23 tahun 2006 tentang Adminitrasi Kependudukan, sebab yang dimaksud dengan Dokumen Kependudukan meliputi biodata penduduk, KK, KTP, surat keterangan kependudukan, akta pencatatan sipil. Sedangkan surat keterangan kependudukan sebagaimana dimaksud pada ayat (1) huruf $d$ meliputi surat keterangan pindah, surat keterangan pindah datang, surat keterangan pindah ke luar negeri, surat keterangan datang dari luar negeri, surat keterangan tempat tinggal, surat keterangan kelahiran, surat keterangan lahir mati, surat keterangan pembatalan perkawinan, surat keterangan pembatalan perceraian, surat keterangan kematian, surat keterangan pengangkatan anak, surat keterangan pelepasan kewarganegaraan Indonesia, surat keterangan pengganti tanda identitas dan surat keterangan pencatatan sipil. Sedangkan pengguna SKD termasuk pemeluk Parmalim tidak ada memiliki dokumen tersebut di atas seperti yang diatur dalam Undang-undang Adminstrasi Kependudukan.

Komisi Pemilihan Umum menjadikan SKD sebagai identitas warga yang hanya digunakan sebagai dokumen adminstrasi dalam pendataan pemilih. SKD dijadikan sebagai identitas lainnya yang diatur dalam Peraturan Komisi Pemilihan Umum (PKPU) Nomor 4 Tahun 2015 Tentang Pemutakhiran Data dan Daftar Pemilih Dalam Pemilihan Gubernur dan Wakil Gubernur, Bupati dan Wakil Bupati, dan/atau Walikota dan Wakil Walikota pasal 1 angka (27).

DalamPKPUNomor 4 Tahun 2015, identitas lain adalah dokumen kependudukan resmi yang diterbitkan instansi pelaksana yang mempunyai kekuatan hukum sebagai alat bukti otentik yang dihasilkan dari pelayanan pendaftaran penduduk dan pencatatan sipil, yakni paling rendah oleh desa/ kelurahan atau sebutan lain oleh pejabat yang berwenang sesuai dengan keputusan atau peraturan daerah di wilayah tempat tinggal masing-masing sebagaimana yang dimaksud dalam undang-undang kependudukan, meliputi resi atau surat keterangan domisili tempat tinggal. Begitu juga pasal 4 ayat (2) huruf c yang menyebutkan berdomisili di daerah Pemilihan paling kurang 6 (enam) bulan sebelum disahkannya DPS yang dibuktikan dengan Kartu Tanda Penduduk (KTP) atau dokumen kependudukan dari instansi yang dikeluarkan oleh instansi atau pejabat yang berwenang. Dalam hal ini KPU mempunyai persepsi jika Kepala Desa/Lurah adalah instansi atau pejabat yang berwenang.

\section{SIMPULAN}

Hasil dari Pemilu yang berintegritas adalah merupakan cita-cita dan wujud dari integritas Pemilu itu sendiri tanpa ada diskriminasi yang didasarkanpadaaturanyangada.Keadaantersebut mencerminkan betapa tingginya integriras dari proses Pemilu tersebut. Berdasarkan pembahasan tersebut di atas disimpulkan bahwa Penggunaan sekaligus akomodir terhadap pengguna SKD merupakan langkah alternatif yang dinilai cukup melindungi hak pilih warga. Bentuk atau upaya pemberian jaminan hak bagi pemilih untuk dapat menggunakan hak pilihnya adalah tersedianya daftar pemilih yang akurat. Hal ini mengingat persyaratan bagi pemilih untuk dapat menggunakan hak pilih adalah terdaftar dalam daftar pemilih. Dengan kata lain 1.285 pemilih pemilih tersebut telah terdaftar dalam 
daftar pemilih, maka pada hari pemungutan suara mereka mendapat jaminan untuk dapat menggunakan hak pilihnya. Demikian pula sebaliknya bila pemilih tidak terdaftar dalam daftar pemilih, maka mereka potensial kehilangan hak pilihnya

Namun beberapa hal yang perlu dipikirkan bahwa kemunculan SKD dikemudian hari, bukan tidak mugkin hal ini akan membuka peluang untuk disusupi kecurangan dan rentan untuk dipolitisasi. Dengan kewengan hanya pada Kepala Desa/Lurah untuk mengeluarkan SKD dalam jumlah banyak, akan membuka peluang memobilisasi penduduk khususnya yang berasal dari Kabupaten/Kota yang sedang tidak menyelenggarakan Pilkada. Dalam hal ini diperlukan adanya peran aktif dan kerjasama antara KPU, Pengawas, Pemantau, Tim Pemenangan, Pemerintah bahkan perwakilan masyarakat dan tokoh agama itu sendiri untuk duduk bersama dalam rangka akurasi daftar pemilih yang yang telah dimutakhirkan. Demikian halnya, jika keberadaan SKD dirasa tidak lagi diakui sebagai dokumen adminitrasi dalam proses pendataan pemilih, maka diperlukan akurasi data kependudukan dari Kemendagri yang terintegrasi secara nasional dengan aplikasi data pemilih di KPU sekaligus upaya meningkatan angka partisipasi masyarakat dalam Pilkada/Pemilu.

\section{DAFTAR PUSTAKA}

Asnawaty. (2013). Komunitas Ugamo Malim atau Parmalim di Desa Tomok dan Desa Hutatunggi Prov. Sumatera Utara, Jurnal Multikultural \& Multireligius Vol. 12

Asy'ari, H. (2012). Arah Sistem Pendaftaran Pemilih Indonesia: Belajar dari Pengalaman Menuju Perbaikan. Jurnal Pemilu dan Demokrasi, 1.

BPS SUMUT. (2016). Indeks Demokrasi Indonesia (IDI) Sumatera Utara 2015. Berita Resmi Statistik Sumatera Utara.

Budiman, A. (2015). Strategi Mewujudkan Pemilu Berkualitas dan Berintegritas. kuliah umum di Universitas Jember, Jawa Timur.

Crcs.ugm.ac.id. (2017, Mei 3). Diakses pada 7 Mei 2017 dari http://crcs.ugm.ac.id/ news/10803/menguji-uu-adminduk- diskriminasi-dalam-pengosongan-kolomagama.html

Creswell, J.W. (2016). Research Design; Pendekatan Metode Kualitatif, Kuatitatif, dan Campuran. Yogyakarta: Pustaka Pelajar.

Detik News. (2017, Mei 8). Diakses pada 28 September 2017, darichttps://news.detik. com/berita/d3494938/pemerintah-setujupenghayat-kepercayaan-tertulis-dikolom-agama-ktp

Ditjenpp.kemenkumham.go.id. Diakses pada 16 Januari 2018 darihttp://ditjenpp. kemenkumham.go.id/htn-dan-puu/2941hak-politik-warga-negara-sebuahperbandingan-konstitusi.html

DKPP RI. (2015). Penyelenggara Pemilu di Dunia; Sejarah, Kelembagaan, dan Praktik Pemilu di Negara Penganut Sistem Pemerintahan Presidensial, SemiPresidensial dan Parlementer. Jakarta: DKPP RI.

Nasef, M.I. (2014). Kewenangan Dewan Kehormatan Penyelenggara Pemilu dalam mengawal Electoral Integrity di Indonesia. Jurnal Hukum IUS QUIA IUSTUM , 285.

Nuryanti, S. (2017). Hilangnya Suara Warga Negara, Jebakan Formalisme dan Perumitan dalam regime elektoral. Disertasi,FISIP-UGM, 488.

Pintor, R.L., \& Gratschew, M. (2002). Voter Registration; Voter's Turnout since 1945. New York: International IDEA.

Ramlan S.D.S. (2011). Sei Demokrasi Elektoral Buku 9: Meningkatkan Akurasi Daftar Pemilih; Mengatur Kembali Sistem Pemutakhiran Daftar Pemilih. Jakarta: Kemitraan.

Santoso, T. (2006). Penegakan Hukum Pemilu, Praktik Pemilu 2004 , Kajian Pemilu 2014-2019. Jakarta: Perludem.

Sitohang, N. (2016) Relasi Parmalim dengan Agama yang dilayani dan diakui oleh Negara, SKRIPSI, FISIP-USU,80

Supriyanto, D. (2007). Menjaga Independensi Penyelenggara Pemilu. Jakarta: Yayasan Perludem. 